\title{
Effects of morphine or tramadol on thiopental anesthetic induction dosage and physiologic variables in halothane anesthetized dogs
}

\author{
Efeitos da morfina ou tramadol na dosagem para indução anestésica \\ de tiopental e nas variáveis fisiológicas em cães anestesiados com halotano \\ Cláudio Corrêa Natalini ${ }^{1}$, Alexandre da Silva Polydoro ${ }^{2} \&$ Nadia Crosignani ${ }^{2}$
}

\begin{abstract}
Eight dogs were premedicated with tramadol $(1.0 \mathrm{mg} / \mathrm{kg}[0.45 \mathrm{mg} / \mathrm{lb}], \mathrm{IM})$ and the other eight with morphine $(1.0$ $\mathrm{mg} / \mathrm{kg}$ [0.45 mg/lb], IM) 20 minutes prior to anesthetic induction. Anesthesia was induced with thiopental and maintained with halothane in oxygen delivered in a Bain system, with spontaneous respiration. Degree of sedation and occurrence of emesis were evaluated after preanesthetic medication. Dose of thiopental necessary to allow tracheal intubation was recorded and compared between the two groups. Arterial blood gas analyses were done before premedication and at 60 minutes of anesthesia. Tramadol produced no visible sedation and no vomit, while morphine induced a moderate degree of sedation in all dogs and vomit in $62 \%$ of them. Dose requirement of thiopental was significantly higher in the dogs premedicated with tramadol. Dogs premedicated with morphine had significantly higher $\mathrm{PaCO}_{2}$ and lower $\mathrm{pH}$ at 60 minutes of anesthesia. Tramadol is not a reliable sedative and do not induce vomit in healthy dogs. The requirement of subsequent anesthetics may not be significantly reduced as compared with morphine. Dogs premedicated with tramadol are likely to maintain better intraoperative respiratory function than when premedicated with morphine. Clinically, tramadol may be useful for premedication of dogs where vomit is undesirable.
\end{abstract}

Key words: Morphine, tramadol, experimental surgery, experimental anesthesia.

\section{RESUMO}

Oito cães foram premedicados com tramadol $1.0 \mathrm{mg} \cdot \mathrm{kg}^{-1} \mathrm{IM}$ e outros oito com morfina $1.0 \mathrm{mg} . \mathrm{Kg}^{-1}, \mathrm{IM}, 20$ minutos antes da indução anestésica. A anestesia foi induzida com tiopental e mantida com halotano em oxigênio através de um sistema de Bain com ventilação espontânea. O grau de sefdação e a ocorrência de emese foram avaliados após a premedicação. A dose de tiopental necessária para permitir a intubação traqueal foi registrada e comparada entre os dois grupos. Análise de gases sangüíneo foi realizada antes e após a indução e a cada 60 minutos de anestesia. $O$ tramadol não produziu sedação ou vômito, enquanto a morfina induziu vômito em $62 \%$ dos cães e moderada sedação em todos. A dosagem de tiopental foi significativamente maior nos cães premedicados com tramadol. Os cães premedicados com morfina apresentaram $\mathrm{PaCO}_{2}$ significativamente elevada e pH significativamente mais baixo aos 60 minutos de anestesia quando comparados tramadol. $\mathrm{O}$ tramadol não foi eficiente como sedativo e não induz vômito em cães hígidos. Cães premedicados com tramadol podem manter melhor funnção respiratória no período intra-operatório do que os premedicados com morfina. Os autores concluem que o tramadol pode ser a premedicação de escolha quando o vômito é indesejável no período pré-operatório.

Descritores: Morfina, tramadol, cirurgia experimental, anestesia experimental. 


\section{INTRODUCTION}

Morphine is the opioid agonist to which other opioids are compared [21]. It is used for preanesthetic medication in dogs [7]. Vomit and retching are observed after intramuscular administration of morphine in dogs $[1,7,23]$. Morphine depresses the brainstem respiratory centers, reducing alveolar ventilation [20]. Hypotension in addition to decreases in heart rate due to a vagotonic effect also occurs [7].

Tramadol has two mechanism of action. The analgesic effects are mediated by a weak binding to $\mu$-opioid receptors, and by inhibiting noradrenaline and serotonin uptake in the neurons of descending inhibitory pain pathways $[4,17]$. The (+)-enantiomer has high affinity for the m-opioid receptor and inhibits serotonin uptake, whereas the (-)-enantiomer is an inhibitor of norepinephrine uptake [17]. The metabolite, $O$-desmethyltramadol (M1), is active, with 200fold higher affinity for opioid receptors than the parent drug $[18,19]$. The hepatic biotransformation of tramadol is identical in humans and dogs.

Efficacy of tramadol in the management of moderate to severe perioperative pain has been demonstrated in clinical studies in humans [18]. These information are in accordance with findings of studies in humans where tramadol has no clinically relevant cardiopulmonary depressant effects unlike other opioids $[8,15]$. Sedation, nausea and vomiting has been reported with the use of tramadol in humans, but whether similar effects occur in dogs have not been published to date. The results from these studies and the interesting pharmacological profile of tramadol suggest that it may be a useful drug for premedication of dogs undergoing general anesthesia $[9,18,24,25]$. The purpose of this study was to compare the effects of tramadol and morphine on sedation, emesis, thiopental requirement for anesthetic induction and intraoperative respiratory function when used for premedication of dogs undergoing general anesthesia.

\section{MATERIALS AND METHODS}

The study was approved by the Scientific Committee of the Agricultural Center, Universidade Federal de Santa Maria, RS, Brazil, where the study was done. Sixteen adult mixed breed dogs weighing 8.0 $\pm 2.6 \mathrm{~kg}(16 \pm 5.2 \mathrm{lb})($ mean $\pm \mathrm{SD}$; range $5.0-13.6 \mathrm{~kg}$ [10-27.2 lb]) were studied. The animals were undergoing surgery as part of an unrelated study. The surge- ries consisted of a longitudinal incision of two-centimeter of length in each femur followed by application of a biological graft. Each anesthetic and surgical procedure lasted approximately 75 and 60 minutes, respectively. The animals were judged healthy on the basis of physical examination, hematology and serum biochemistry analysis.

Dogs were randomly and equally distributed into two groups to be premedicated with tramadol ${ }^{1}$ or morphine ${ }^{2}$. Both drugs were given intramuscularly at $1.0 \mathrm{mg} / \mathrm{kg}(0.45 \mathrm{mg} / \mathrm{lb}$ and no attempt was made to use equipotent doses of each drug. Morphine was used at a clinically recommended dose, and the dose of tramadol was chosen based on analgesic doses used in humans $[7,18]$. Twenty minutes after premedication, a 20-gauge catheter was placed in the cephalic vein and anesthesia was induced with thiopental at 10 to $25 \mathrm{mg} / \mathrm{kg}$ ( 4.5 to $11.25 \mathrm{mg} / \mathrm{lb}$ ) given to effect to allow tracheal intubation. Anesthesia was maintained with halothane delivered with a calibrated vaporizer and a Bain coaxial system with a fresh gas flow of 200 $\mathrm{ml} / \mathrm{kg} / \mathrm{min}(90 \mathrm{ml} / \mathrm{lb} / \mathrm{min})$. The animals were allowed to breathe spontaneously. Lactated Ringer's solution was administered intraoperatively at $20 \mathrm{ml} / \mathrm{kg} / \mathrm{h}(9$ $\mathrm{ml} / \mathrm{lb} / \mathrm{h}$ ). Body temperature was maintained within the physiologic range with the use of an electric blanket. The investigator performing the anesthesia and the evaluations was unaware of the treatment given for each dog.

Levels of sedation, assessed immediately before catheter placement and resistance to handling during skin preparation (clipping, scrubbing) for catheter placement were evaluated subjectively and classified as none, mild, moderate or marked (Appendix 1). The dose requirement of thiopental to allow tracheal intubation and the vaporizer settings necessary to maintain an appropriate surgical plane of anesthesia were recorded and compared between the two groups. Appropriate surgical anesthesia was maintained by assessing clinical variables such as absence of spontaneous movement and palpebral reflexes, with no or mild jaw tone, and eyes rotated ventro-medially. Time from discontinuation of anesthetic delivery to extubation, as indicated by presence of laryngeal reflex and objection to the tracheal tube, was recorded and compared between groups.

Arterial blood gas analyses ${ }^{3}$ were performed before premedication and at 60 minutes of anesthesia for measurement of arterial partial pressures of oxy- 
gen $\left(\mathrm{PaO}_{2}\right)$, carbon dioxide $\left(\mathrm{PaCO}_{2}\right)$, $\mathrm{pH}$ and bicarbonate $\left(\mathrm{HCO}_{3}^{-}\right)$. Blood samples were collected anaerobically from the femoral artery and kept in ice for no longer then one hour until being analyzed. Other physiologic parameters that were measured before premedication and every 10 minutes after anesthetic induction included heart and respiratory rates, systemic arterial blood pressure, and oxygen saturation of hemoglobin. Heart rate and oxygen saturation of hemoglobin were measured with a pulse oximeter ${ }^{4}$. Respiratory rate was obtained by direct visualization of chest wall or reservoir bag excursions. Systolic, mean and diastolic arterial blood pressures were measured noninvasively ${ }^{5}$ with the cuff (width of approximately $30 \%$ to $40 \%$ of the limb circumference) placed snugly proximally to the carpus. Statistical analysis ${ }^{6}$ of the parametric data was performed with ANOVA or ANOVA for repeated measures with $p<0.05$ considered significant. Data are expressed as mean $\pm \mathrm{SD}$.

\section{RESULTS}

The duration of anesthesia, surgery and body weight of the dogs were similar between the two groups. Premedication with tramadol did not cause emesis, while $62 \%$ ( $5 \mathrm{dogs}$ ) of the dogs vomited after morphine administration. Level of sedation was rated as none for dogs premedicated with tramadol and moderate for those premedicated with morphine. Resistance to handling in the dogs premedicated with tramadol was rated as moderate in $62 \%$ ( $5 \mathrm{dogs})$, and mild in $38 \%$ ( $3 \mathrm{dogs}$ ) of the animals. Of those receiving morphine, resistance to handling was rated as none in $75 \%$ (6 dogs) and mild in 25\% (2 dogs) of the animals.

The dose of thiopental necessary for tracheal intubation was significantly higher for the dogs premedicated with tramadol $(17 \pm 3.8 \mathrm{mg} / \mathrm{kg}[7.65 \pm 1.71$ $\mathrm{mg} / \mathrm{lb}])$ in comparison with morphine $(12 \pm 1.8 \mathrm{mg} / \mathrm{kg}$ $[5.4 \pm 0.81 \mathrm{mg} / \mathrm{lb}])$. Blood gas parameters did not differ between the two groups at baseline. Dogs premedicated with morphine presented higher $\mathrm{PaCO}_{2}$ and lower $\mathrm{pH}$ than with tramadol at 60 minutes of anesthesia. $\mathrm{PaO}_{2}, \mathrm{HCO}_{3}^{-}$(Table 1), heart and respiratory rates, oxygen saturation of hemoglobin, and arterial blood pressure were not significantly different between the two groups at baseline or intraoperatively. Vaporizer settings necessary to maintain an adequate surgical plane of anesthesia were similar between the two groups (Table 2). Dogs premedicated with tramadol were extu- bated significantly earlier $(10.4 \pm 5.3 \mathrm{~min})$ than those premedicated with morphine $(20 \pm 11.3 \mathrm{~min})$.

\section{DISCUSSION}

Tramadol was introduced for use in human medicine in the late 1070s in Germany. It is formulated for oral, parenteral and rectal administration, although only the oral form is approved for use in humans in the United States [18]. In humans, intravenous or intramuscular doses of 50 to $100 \mathrm{mg}$ are commonly used in adults and adolescents, and 1 to $2 \mathrm{mg} /$ $\mathrm{kg}$ are commonly used in pediatric patients in the perioperative period $[5,9,18]$. The intramuscular administration offer similar systemic bioavailability as the intravenous route, with only a slightly slower onset of action that is therapeutically irrelevant [14]. Tramadol undergoes rapid hepatic metabolism in dogs [18]. The main metabolite (M1) is up to six times more potent than tramadol in producing analgesia and 200 times more potent in m-opioid receptor binding $[11,16,18]$. The higher generation of metabolites with strong opioid activity (M1) due to faster metabolism in dogs compared to humans suggests that tramadol may be a stronger analgesic in dogs [11,12]. Hence, although tramadol is considered 5 to 10 time less potent than morphine in humans, no attempt was

Table 1. Mean \pm SD of blood gas values at baseline and 60 minutes of anesthesia in dogs premedicated intramuscularly with $1.0 \mathrm{mg} / \mathrm{kg}(0.45 \mathrm{mg} / \mathrm{lb})$ of either tramadol ( $\mathrm{T})$ or morphine (M) undergoing general anesthesia for orthopedic surgery ( $\mathrm{n}=8 /$ group).

\begin{tabular}{ccc}
\hline \multirow{2}{*}{ Variable and group } & \multicolumn{2}{c}{ Time } \\
\cline { 2 - 3 } pH & Baseline & 60 minutes \\
\hline T & $7.37 \pm 0.06^{\mathrm{a}}$ & $7.25 \pm 0.02^{\mathrm{a}}$ \\
M & $7.39 \pm 0.01^{\mathrm{a}}$ & $7.20 \pm 0.01^{\mathrm{b}}$ \\
\hline Partial pressure of carbon dioxide & & \\
T & $38.4 \pm 4.6^{\mathrm{a}}$ & $49.3 \pm 3.1^{\mathrm{a}}$ \\
M & $35.0 \pm 1.9^{\mathrm{a}}$ & $59.6 \pm 2.4^{\mathrm{b}}$ \\
\hline Partial pressure of oxygen & & \\
T & $87.03 \pm 6.2^{\mathrm{a}}$ & $339.6 \pm 32.5^{\mathrm{a}}$ \\
M & $84.2 \pm 12.0^{\mathrm{a}}$ & $355.0 \pm 50.8^{\mathrm{a}}$ \\
\hline Bicarbonate & & \\
\hline T & $21.5 \pm 0.7^{\mathrm{a}}$ & $20.9 \pm 0.6^{\mathrm{a}}$ \\
\hline & $19.4 \pm 4.2^{\mathrm{a}}$ & $22.3 \pm 0.7^{\mathrm{a}}$ \\
\hline
\end{tabular}

Different letters at the same column indicate statistically significant differences $(p<0.05)$ between groups for the respective variable. 
Table 2. Physiologic measurements and vaporizer settings (Mean \pm SD) in dogs premedicated intramuscularly with $1.0 \mathrm{mg} / \mathrm{kg}$ $(0.45 \mathrm{mg} / \mathrm{lb})$ of either tramadol $(\mathrm{T})$ or morphine $(\mathrm{M})$ undergoing general anesthesia for orthopedic surgery ( $\mathrm{n}=8 /$ group).

\begin{tabular}{|c|c|c|c|c|c|c|c|}
\hline \multirow[t]{2}{*}{ Variable and group } & \multicolumn{7}{|c|}{ Time (minutes after anesthetic induction) } \\
\hline & $\begin{array}{c}\text { Before } \\
\text { premedication }\end{array}$ & 10 & 20 & 30 & 40 & 50 & 60 \\
\hline \multicolumn{8}{|c|}{ Respiratory rate (breathes/min) } \\
\hline $\mathrm{T}$ & $24.2 \pm 17.9$ & $21.1 \pm 9.7$ & $24.9 \pm 13.6$ & $18.4 \pm 9.8$ & $17.9 \pm 12.0$ & $22.1 \pm 15.2$ & $22.6 \pm 12.2$ \\
\hline M & $26.6 \pm 6.7$ & $13.7 \pm 4.8$ & $18.3 \pm 9.6$ & $15.9 \pm 6.7$ & $19.8 \pm 6.6$ & $19.4 \pm 13.1$ & $21.3 \pm 11.9$ \\
\hline \multicolumn{8}{|c|}{ Pulse oximetry (\% saturation) } \\
\hline $\mathrm{T}$ & $94.8 \pm 3.1$ & $100 \pm 0.0$ & $99.4 \pm 1.3$ & $99.2 \pm 0.8$ & $99.7 \pm 0.5$ & $99.7 \pm 0.5$ & $99.7 \pm 0.8$ \\
\hline M & $94.8 \pm 2.7$ & $99.7 \pm 0.8$ & $99.5 \pm 0.8$ & $99.8 \pm 0.4$ & $100 \pm 0.0$ & $99.8 \pm 0.4$ & $99.8 \pm 0.4$ \\
\hline \multicolumn{8}{|l|}{ Heart rate (beats/min) } \\
\hline $\mathrm{T}$ & $93.4 \pm 21.3$ & $142 \pm 25.9$ & $117.4 \pm 36.9$ & $135.4 \pm 24.2$ & $107.1 \pm 22.6$ & $99.8 \pm 15.1$ & $101.5 \pm 20.3$ \\
\hline M & $95.6 \pm 15.2$ & $142.5 \pm 29.5$ & $135 \pm 19.3$ & $119 \pm 16.4$ & $113 \pm 16.3$ & $108.9 \pm 20.8$ & $107.9 \pm 18.9$ \\
\hline \multicolumn{8}{|c|}{ Systolic arterial pressure $(\mathrm{mmHg})$} \\
\hline $\mathrm{T}$ & $121.8 \pm 27.6$ & $119.6 \pm 19.1$ & $105.1 \pm 21.7$ & $124.1 \pm 26.9$ & $111.6 \pm 18.0$ & $104.6 \pm 19.2$ & $111 \pm 17.5$ \\
\hline M & $147.2 \pm 10.2$ & $108 \pm 18.4$ & $113.3 \pm 18.3$ & $121.6 \pm 19.2$ & $107.7 \pm 20.5$ & $108.6 \pm 24.4$ & $106.9 \pm 21.8$ \\
\hline \multicolumn{8}{|c|}{ Mean arterial pressure $(\mathrm{mmHg})$} \\
\hline $\mathrm{T}$ & $106.2 \pm 32.0$ & $94.3 \pm 18.6$ & $79 \pm 18.5$ & $100.3 \pm 22.9$ & $87.3 \pm 17.8$ & $83.7 \pm 12.8$ & $85.1 \pm 18.6$ \\
\hline M & $116.2 \pm 11.9$ & $81.6 \pm 15.2$ & $91 \pm 13.9$ & $94.3 \pm 18$ & $80.3 \pm 18.8$ & $85 \pm 19.3$ & $80.3 \pm 16.9$ \\
\hline \multicolumn{8}{|c|}{ Diastolic arterial pressure $(\mathrm{mmHg})$} \\
\hline $\mathrm{T}$ & $88.8 \pm 25.2$ & $77.7 \pm 21.0$ & $66.4 \pm 20.2$ & $87.8 \pm 21.1$ & $73.9 \pm 16.9$ & $73 \pm 14.4$ & $73.7 \pm 21.6$ \\
\hline M & $99.4 \pm 14.6$ & $72.7 \pm 14.6$ & $79.4 \pm 10.2$ & $76.9 \pm 21.5$ & $67.7 \pm 19.8$ & $72.4 \pm 19.4$ & $69 \pm 13.8$ \\
\hline \multicolumn{8}{|c|}{ Vaporizer settings (volumes \%) } \\
\hline $\mathrm{T}$ & - & $2.0 \pm 0.0$ & $1.8 \pm 0.2$ & $1.6 \pm 0.3$ & $1.3 \pm 0.4$ & $1.2 \pm 0.4$ & $1.1 \pm 0.3$ \\
\hline M & - & $2.0 \pm 0.0$ & $1.9 \pm 0.1$ & $1.4 \pm 0.3$ & $1.1 \pm 0.3$ & $1.0 \pm 0.2$ & $1.0 \pm 0.2$ \\
\hline
\end{tabular}

There was no statistically significant difference $(\mathrm{p}<0.05)$ for each variable between the two groups.

made to use equipotent doses of morphine and tramadol in this study in dogs [18].

Sedation may occur with the use of opioids in dogs and humans and may be desirable in the preoperative period [7,21]. In humans, studies have demonstrated that tramadol produces sedation comparable to morphine at equianalgesic doses $[2,3,5,6]$. In the present study, while morphine produced a moderate degree of sedation, no visible sedation was noticed in the dogs premedicated with tramadol. The lack of sedative effects in the dogs premedicated with tramadol made preoperative handling of the animals more difficult and reflected in a higher requirement of thiopental for anesthetic induction in comparison with morphine. Tramadol does not appear to be useful for preoperative sedation of healthy dogs. The use of higher doses is also unlike to increase sedation as tramadol was shown to increase CNS activity in a dosedependent manner [13].
Morphine stimulates the vomit center resulting in a high incidence of emesis in dogs and humans $[1,7,21,23]$. In humans, tramadol has been associated with a similar or lower frequency of nausea and vomiting when compared to equianalgesic doses of morphine $[1,23]$. Tramadol did not induce vomit in any dog in the present study indicating that the incidence of vomiting associated with tramadol administration in dogs may be lower than in humans. A high incidence of vomiting was observed in the dogs premedicated with morphine, in accordance with previously reported studies $[1,23]$. One study found that previous administration of acepromazine, a tranquilizer with anti-emetic properties commonly used in dogs, may reduce the incidence of opioid-induced vomit in dogs, but does not eliminate it [23]. The apparent lack of emetic action of tramadol in dogs may be useful clinically in occasions where vomit should be avoided and yet the administration of an opioid is necessary. 
Absence of clinically significant respiratory depression is considered one of the greatest advantages of using tramadol for pain control in humans in comparison with other opioids. Large doses of tramadol and meperidine in non-anesthetized volunteers produced significant respiratory depression with meperidine but not with tramadol. Administered equivalent doses of tramadol and meperidine intravenously to enflurane-anesthetized patients produced no respiratory depression in the group receiving tramadol. At 1.5 times the equipotent dose, tramadol decreased the respiratory rate but had no effect on end-tidal carbon dioxide tension, while morphine caused significant depression of ventilation or even apnea in human beings anesthetized with halothane. [2,8,13,18,22].

The respiratory depressant effects of morphine administered to anesthetized dogs are well-known, but only two studies have evaluated the respiratory effects of tramadol in dogs. In one experimental study, did not observe respiratory depression in awake or anesthetized dogs given tramadol intravenously at doses up to $10 \mathrm{mg} / \mathrm{kg}$ (4.5 mg/lb) [8]. In 1 clinical study, the authors compared the intravenous administration of tramadol with morphine in isoflurane-anesthetized dogs, and observed significantly higher end-tidal carbon dioxide tension at 30 minutes of anesthesia in the animals receiving morphine [15]. In the study reported here, a more pronounced respiratory depression was seen in the dogs premedicated with morphine, as evidenced by a significantly higher $\mathrm{PaCO}_{2}$. It is unlike that this difference was caused only by the inhalant anesthetic since the animals were maintained in a clinically similar anesthetic depth and the vaporizer settings were similar between the two groups. Furthermore, the respiratory findings are in accordance with the results reported previously in dogs and humans, showing that tramadol may prove particularly useful in patients with limited respiratory function.

In conclusion, tramadol is not a reliable sedative and do not induce vomit in healthy dogs. Patients on tramadol will require significantly higher thiopental doses for anesthetic induction as compared with morphine. Dogs premedicated with tramadol are likely to maintain better intraoperative respiratory function than when premedicated with morphine. Clinically, tramadol may be useful for premedication of dogs where vomit is undesirable, or in patients predisposed to respiratory depression.

\section{SOURCES AND MANUFACTURERS}

${ }^{1}$ Tramon, Cristália Produtos Quimicos e Farmaceuticos, Itapira, SP, Brazil.

${ }^{2}$ Dimorf, Cristalia Produtos Quimicos e Farmaceuticos, Itapira, SP, Brazil.

${ }^{3}$ AVL AG900, Biomedical Instruments, Switzerland.

${ }^{4}$ Nellcor N-200, Nellcor Inc., Pleasanton, CA, USA.

${ }^{5}$ Dinamap-Critikon, Tampa, FL, USA.

${ }^{6}$ SigmaStat for Windows version 2.03, SPSS Inc., Chicago, IL, USA.

\section{REFERENCES}

1 Barnhart M.D., Hubbell J.A. \& Muir W.W. 2000. Pharmacokinetics, pharmacodynamics, and analgesic effects of morphine after rectal, intramuscular, and intravenous administration in dogs. American Journal of Veterinary Research. 61: 24-28.

2 Bloch M.B., Dyer R.A. \& Heijke S.A. 2003. Tramadol infusion for postthoracotomy pain relief: a placebo-controlled comparison with epidural morphine. Anesthesia \& Analgesia. 94: 523-528.

3 Coetzee J.F., Maritz J.S. \& du Toit JC. 1996. Effect of tramadol on depth of anaesthesia. British Journal of Anaesthesia. 76: 415-418.

4 Driessen B. \& Reimann W. 1992. Interaction of the central analgesic, tramadol, with the uptake and release of 5-hydroxytryptamine in the rat brain in vitro. British Journal of Pharmacology. 105: 147-151.

5 Engelhardt T., Steel E., Johnston G. \& Veitch D.Y. 2003. Tramadol for pain relief in children undergoing tonsillectomy: a comparison with morphine. Paediatric Anaesthesia. 13: 249-252.

6 Erolçay H. \& Yüceyar L. 2003. Intravenous patient-controlled analgesia after thoracotomy: a comparison of morphine with tramadol. European Journal of Anaesthesiology. 20: 141-146.

7 Hall L.W., Clarke K.W. \& Trim C.M. 2001. Anesthesia of the dog. In: Hall L.W., Clarke K.W. \& Trim C.M. Veterinary Anaesthesia. 10th edn. London: WB Saunders Co, pp.385-439.

8 Houmes R.J., Voets M.A. \& Verkaaik A. 1992. Efficacy and safety of tramadol versus morphine for moderate and severe postoperative pain with special regard to respiratory depression. Anesthesia \& Analgesia. 74: 510-514.

9 Lee C.R., McTavish D. \& Sorkin E.M. 1993. Tramadol. A preliminary review of its pharmacodynamic and pharmacokinetic properties, and therapeutic potential in acute and chronic pain states. Drugs. 46: 313-340. 
10 Lintz W., Beier H. \& Gerloff J. 1999. Bioavailability of tramadol after i.m. injection in comparison to i.v. infusion. International Journal Clinical Pharmacology and Therapeutics. 37: 175-183.

11 Lintz W., Erlacin S., Frankus E. \& Uragg H. 1981. Metabolismus von tramadol bei mensch und tier. Arzneimittelforschung. 31: 1932-1943.

12 Mastrocinque S. \& Fantoni D.T. 2003. A comparison of preoperative tramadol and morphine for the control of early postoperative pain in canine ovariohysterectomy. Veterinary Anaesthesia and Analgesia. 30: 220-228.

13 Mildh L.H., Leino K.A. \& Kirvela O.A. 1999. Effects of tramadol and meperidine on respiration, plasma catecholamine concentrations, and hemodynamics. Journal of Clinical Anesthesia. 11: 310-316.

14 Ng K.F., Tsui S.L., Yang J.C. \& Ho E.T. 1998. Increased nausea and dizziness when using tramadol for post-operative patient-controlled analgesia (PCA) compared with morphine after intraoperative loading with morphine. European Journal of Anaesthesiology. 15: 565-570.

15 Osterloh G., Friderichs E. \& Felgenhauer F. 1978. General pharmacological studies on tramadol, a potent analgetic agent. Arzneimittelforschung. 28: 135-1351.

16 Raffa R.B., Friderichs E. \& Reimann W. 1992. Opioid and nonopioid components independently contribute to the mechanism of action of tramadol, an 'atypical' opioid analgesic. Journal of Pharmacology and Experimental Therapeutics. 260: 275-285.

17 Raffa R.B., Friderichs E. \& Reimann W. 1993. Complementary and synergistic antinociceptive interaction between the enantiomers of tramadol. Journal of Pharmacology and Experimental Therapeutics. 267: 331-340.

18 Scott L.J. \& Perry C.M. 2000. Tramadol: a review of its use in perioperative pain. Drugs. 60:139-176.

19 Sevcik J., Nieber K. \& Driessen B. 1993. Effects of the central analgesic tramadol and its main metabolite, O-desmethyltramadol, on rat locus coeruleus neurones. British Journal of Pharmacology. 110: 169-176.

20 Steffey E.P., Eisele J.H. \& Baggot J.D. 1993. Influence of inhaled anesthetics on the pharmacokinetics and pharmacodynamics of morphine. Anesthesia \& Analgesia. 77: 346-351.

21 Stoelting R.K. 1999. Opioid agonists and antagonists. In: Stoelting R.K. (Ed). Pharmacology and physiology in anesthetic practice. 3rd edn. Philadelphia: Lippincott Willias \& Wilkins Co, pp.77-112.

22 Tarkkila P., Tuominen M. \& Lindgren L. 1998. Comparison of respiratory effects of tramadol and pethidine. European Journal of Anaesthesiology. 15: 64-68.

23 Valverde A., Cantwell S. \& Hernandez J. 2002. Effects of acepromazine on the incidence of vomiting associated with opioid administration in dogs. In: Proceedings of the American College of Veterinary Anesthesiology 27th Annual Meeting (Orlando, U.S.A.). p.13.

24 Vergnion M., Degesves S. \& Garcet L. 2001. Tramadol, an alternative to morphine for treating postraumatic pain in the prehospital situation. Anesthesia \& Analgesia. 92: 1543-1546.

25 Vickers M.D., O'Flaherty D. \& Szekely S.M. 1992. Tramadol: pain relief by an opioid without depression of respiration. Anaesthesia. 47: 291-296. 